\title{
IDENTITAS PETANI YANG MEMPENGARUHI PENDAPATAN BAGI USAHATANI PADI SAWAH DI KOTA BAUBAU
}

\author{
Hardin \\ Program Studi Agribisnis Fakultas Peranian \\ Universitas Muhammadiyah Buton \\ Jl. Betoambari No. 36 Baubau \\ e-mail: hardin@umbuton.ac.id
}

\begin{abstract}
The internal variables that can increase productivity and income, including schooling, age, arable land size and the number of dependents and the experience of agriculture and social status are all linked to the identity of farmers. The aim of this study is: (1) Empirically demonstrate that the age of farmers is influenced by rice farming income in the village of Ngkaringkaring, subdistrict of Bungi and city of Baubau; (2) empirically demonstrate that there is an impact on rice crop income in Ngkaringkaring Village and Bungi Subdistrict and Baubau City on farmers ' education; (3) Demonstrate empirically whether the number of dependents of the farming family has an impact on the income of lowland rice farming in Ngkaringkaring Village, subdistrict of Bungi, the city of Baubau; (4) Demonstrate empirically whether farmers ' experience has an impact on the income of lowland rice farming in Ngkaringkaring Village, subdistrict of Bungi, Baubau City; (5) (5) To prove empirically whether farmers have an impact on the income of lowland rice farmers in Ngkaringkaring Village, subdistrict of Bungi, Baubau City; (6) To prove empirically whether the social status of farmers has an impact on the income of rice farming in Ngkaringkaring Village, subdistrict of Bungi, Baubau City. The technique used is a multi-linear regression method. The results of this study are: (1) The level of education and area of arable land and the effect of income on lowland rice farming with a probability value of 0.000 each well below 0.05 means that HO is rejected and $\mathrm{H} 2$ and $\mathrm{H} 5$ accepted; (2) Age, farming experience, number of family dependents and social status do not affect rice farming income, as each has a probably. (3) The identity of the respondent farmers (age, level of education, farming experience, number of family dependents, area of arable land and social status) together contributed 96.4 percent to the income effect on lowland rice farming, while the remaining 3.6 percent were affected by other factors.
\end{abstract}

Keywords: Farmer Identity, Rice Field Farming Income

\begin{abstract}
Abstrak
Faktor internal yang dapat meningkatkan produksi dan produktivitas serta pendapatan petani padi sawah, yaitu menyangkut identitas yang dimiliki oleh para petani baik yang meliputi pendidikan, umur, luas lahan garapan, jumlah tanggungan keluarga, dan pengalaman berusahatani serta status sosial. Tujuan dari penelitian ini adalah: (1) Untuk membuktikan secara empiris apakah terdapat pengaruh umur petani terhadap pendapatan usahatani padi sawah di Kelurahan Ngkaringkaring Kecamatan Bungi Kota Baubau.; (2) Untuk membuktikan secara empiris apakah terdapat pengaruh tingkat pendidikan petani terhadap pendapatan usahatani padi sawah di Kelurahan Ngkaringkaring Kecamatan Bungi Kota
\end{abstract}


Baubau; (3) Untuk membuktikan secara empiris apakah terdapat pengaruh jumlah tanggungan keluarga petani terhadap pendapatan usahatani padi sawah di Kelurahan Ngkaringkaring Kecamatan Bungi Kota Baubau; (4) Untuk membuktikan secara empiris apakah terdapat pengaruh pengalaman berusahatani petani terhadap pendapatan usahatani padi sawah di Kelurahan Ngkaringkaring Kecamatan Bungi Kota Baubau; (5) Untuk membuktikan secara empiris apakah terdapat pengaruh luas lahan garapan petani terhadap pendapatan usahatani padi sawah di Kelurahan Ngkaringkaring Kecamatan Bungi Kota Baubau; (6) Untuk membuktikan secara empiris apakah terdapat pengaruh status sosial petani terhadap pendapatan usahatani padi sawah di Kelurahan Ngkaringkaring Kecamatan Bungi Kota Baubau. Analisis yang digunakan adalah analisis regresi linear berganda. Hasil penelitian ini adalah: (1) Tingkat Pendidikan dan luas lahan garapan dan memberikan pengaruh terhadap pendapatan pada usahatani padi sawah dengan nilai probabilitas masingmasing 0,000 dimana berada jauh di bawah 0,05, berarti $\mathrm{H} 0$ ditolak dan $\mathrm{H} 2$ dan $\mathrm{H} 5$ diterima; (2) Umur, pengalaman berusahatani, jumlah tanggungan keluarga dan status sosial tidak memberikan pengaruh terhadap pendapatan pada usahatani padi sawah, karena masingmasing memiliki nilai probabilitas yaitu 0,640, 0,666, 0,574 dan 0.648 lebih besar dari 0,05 berarti H0 diterima dan H1, H3, H4 dan H6 ditolak; (3) Identitas petani responden (umur, tingkat pendidikan, pengalaman berusahatani, jumlah tanggungan keluarga, luas lahan garapan serta status sosial) secara bersama-sama memberikan konstribusi pengaruh terhadap pendapatan pada usahatani padi sawah sebesar 96,4\% dan selebihnya yaitu 3,6\% dipengaruhi oleh faktor-faktor lain.

Kata Kunci: Identitas Petani, Pendapatan Usahatani Padi Sawah

\section{PENDAHULUAN}

Kebijakan pembangunan pertanian yang ditujukan untuk meningkatkan ketahanan pangan, mengembangkan agribisnis dan meningkatkan kesejahteraan petani, mengisyaratkan bahwa produk pertanian yang dihasilkan harus memenuhi syarat kuantitas, kualitas dan kontinuitas sehingga memiliki daya saing dan mudah diperoleh dengan harga yang terjangkau. Produksi komoditi utama tanaman pangan (padi, jagung dan kedelai) meskipun meningkat setiap tahunnya namun belum dapat memenuhi kebutuhan dalam negeri, baik kuantitas maupun kualitasnya. Agribisnis padi tidak dapat dipisahkan dari kehidupan sosial dan ekonomi bagi sebagian besar masyarakat Indonesia, bahkan komoditas pangan ini adakalanya turut mempengaruhi tatanan politik dan stabilitas nasional. Selain sebagai makanan pokok lebih dari $95 \%$ penduduk, padi telah menjadi sumber mata pencaharian sebagian besar petani di pedesaan. Di beberapa daerah, sebagian penduduk telah menjadikan jagung dan ubi jalar sebagai makanan utama.

Usahatani padi dan palawija di Indonesia berkembang dari pertanian subsisten yang semula hanya bertujuan untuk memenuhi kebutuhan pangan keluarga menjadi usahatani komersial. Perubahan paradigma ini dipicu oleh pergeseran ekonomi dan kemajuan teknologi pertanian. Akan tetapi, usahatani padi dan palawija hingga saat ini belum mampu memberikan nilai tambah yang layak bagi keluarga petani, maupun secara keseluruhan telah memberikan kontribusi yang besar bagi perekonomian nasional. Disatu sisi, produksi padi dan palawija perlu ditingkatkan untuk memenuhi kebutuhan pangan penduduk yang terus bertambah. Disisi lain, tantangan yang dihadapi dalam pengadaan produksi makin berat. 
Laju pertumbuhan penduduk yang masih tinggi dan sebagian lahan subur telah terkonversi untuk keperluan non pertanian tanaman pangan adalah bagian dari tantangan yang harus dicarikan jalan keluarnya. Perubahan iklim global juga menjadi ancaman bagi upaya peningkatan produksi tanaman pangan. Di beberapa negara penghasil beras, perubahan iklim telah menurunkan produksi padi karena tanaman didera kekeringan pada musim kemarau dan kebanjiran pada musim hujan. Hal ini berdampak pada menipisnya stok beras di pasar internasional yang berujung pada peningkatan harga bahan pangan (Widiarta, I.N. dkk., 2010:1).

Sejalan dengan hal tersebut, jika kita melihat data dari Dinas Pertanian Kota Baubau, sebagian besar masyarakat Kota Baubau mengusahakan padi sawah dan padi ladang yang tersebar di 3 (tiga) kecamatan yaitu Kecamatan Bungi, Kecamatan Lea-Lea dan Kecamatan Sorawolio. Untuk lebih jelasnya mengenai padi sawah dapat dilihat pada Tabel 2.

Tabel 2. Pelaksanaan Luas Tanam, Luas Panen, Produksi dan Produktivitas Padi Sawah Perkecamatan di Kota Baubau dari Tahun 2011-2016

\begin{tabular}{llllll}
\hline No & Komoditas/ & & Luas & Luas Panen & Produksi \\
Tahun & Kecamatan & Tanam $(\mathrm{Ha})$ & $(\mathrm{Ha})$ & (Ton) & (Ton/Ha)
\end{tabular}

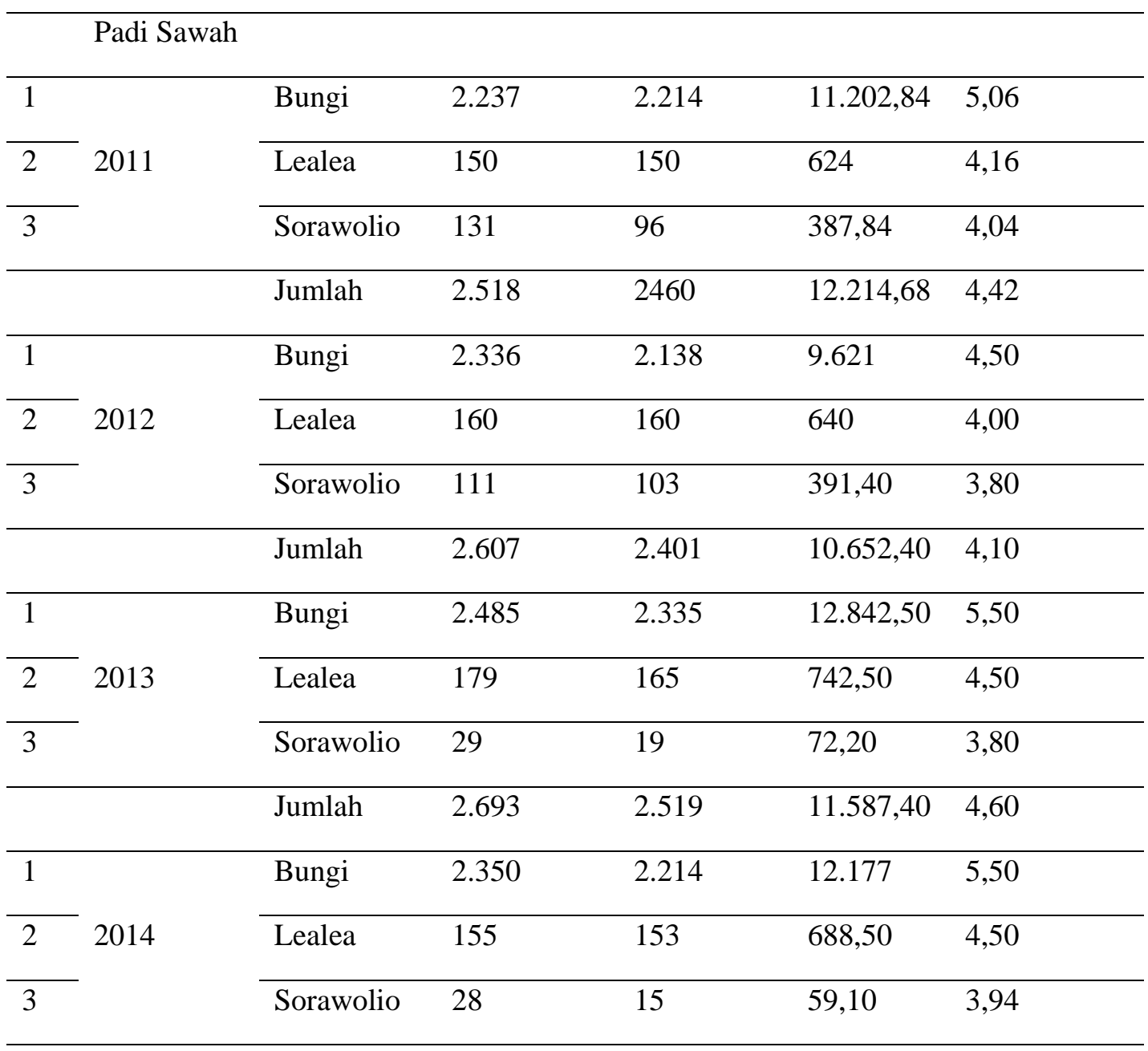


Vol. 3, Issue 2, November 2019

P-ISSN: 2527-8479 E-ISSN: 2686-2174

\begin{tabular}{|c|c|c|c|c|c|c|}
\hline & & Jumlah & 2.533 & 2.382 & $11.068,36$ & 4,65 \\
\hline 1 & \multirow{3}{*}{2015} & Bungi & 2.016 & 2.016 & $11.289,6$ & 5,60 \\
\hline 2 & & Lealea & 186 & 186 & 809,1 & 4,35 \\
\hline \multirow[t]{2}{*}{3} & & Sorawolio & 7 & 7 & 24,29 & 3,47 \\
\hline & & Jumlah & 2.209 & 2.209 & $9.807,96$ & 4,44 \\
\hline 1 & \multirow{4}{*}{2016} & Bungi & 2.141 & 2.141 & 10900,02 & 5,09 \\
\hline 2 & & Lealea & 230 & 230 & 977,50 & 4,25 \\
\hline \multirow[t]{2}{*}{3} & & Sorawolio & 17 & 14 & 44,10 & 3,15 \\
\hline & & Jumlah & 2.388 & 2.388 & $11.921,62$ & 4,16 \\
\hline
\end{tabular}

Sumber: Dinas Pertanian Kota Baubau Tahun 2017

Berdasarkan Tabel 2. menunjukkan bahwa produksi padi sawah di Baubau mengalami fluktuasi dari tahun ke tahun, disebabkan karena faktor iklim, berupa gagal panen karena banjir yang merendam sebagian daerah persawahan sehingga para petani melakukan panen dini contohnya tahun 2015 produksi padi sebesar 9.807,96 ton, sangat rendah jika dibandingkan dengan tahun sebelumnya maupun tahun 2016. Produksi padi tersebut dalam bentuk Gabah Kering Panen (GKP), sehingga untuk mengetahui berapa besar produksi beras di Kota Baubau harus dikonversi ke Gabah Kering Giling (GKG) dengan nilai konversi adalah 0,8602 x GKP, kemudian untuk menjadi beras harus dikonversi dengan nilai konversi yaitu 0,6274 x GKG. Untuk mengetahui ketersediaan beras yang berasal dari hasil produksi sawah di Kota Baubau untuk tahun 2016 yaitu 6433,97 ton/tahun.

Dalam rangka meningkatkan produksi dan produktivitas serta pendapatan petani padi sawah maka ada beberapa faktor yang perlu diperhatikan bagi para petani, baik yang menyangkut faktor eksternal maupun yang menyangkut faktor internal. Adapun yang menjadi faktor eksternal yaitu sejalan dengan program peningkatan ketahanan pangan seperti yang dikemukakan oleh Yauri Tetanel (2010:25) dimana program tersebut bertujuan untuk memfasilitasi peningkatan dan keberlanjutan ketahanan pangan sampai ke tingkat rumah tangga sebagai bagian dari ketahanan nasional. Kegiatan pokok yang dilakukan dalam program ini meliputi: (1) Optimalisasi dan perluasan areal pertanian (ekstensifikasi); (2) Peningkatan penggunaan teknologi dan input pertanian (intensifikasi); (3) Pengamanan lahan sawah di daerah irigasi; (4) Peningkatan pasca panen dan pengolahan hasil, melalui optimalisasi pemanfaatan alat dan mesin pertanian untuk pasca panen dan pengolahan hasil, serta pengembangan dan pemanfaatan teknologi pertanian untuk menurunkan kehilangan hasil (looses); (5) Peningkatan distribusi pangan, melalui penguatan kapasitas kelembagaan pangan dan peningkatan infrastruktur pedesaan yang mendukung sistem distribusi pangan, untuk menjamin keterjangkauan masyarakat atas pangan; (6) Diversifikasi pangan, melalui peningkatan ketersediaan pangan hewani, buah dan sayuran, perekayasaan sosial terhadap pola konsumsi masyarakat menuju pola pangan dengan mutu yang semakin meningkat, dan peningkatan minat dan kemudahan konsumsi pangan alternatif/pangan lokal; dan (7) Pencegahan dan penanggulangan masalah pangan, melalui peningkatan bantuan pangan 
kepada keluarga miskin/rawan pangan, peningkatan pengawasan mutu dan keamanan pangan, dan pengembangan sistem antisipasi dini terhadap kerawanan pangan.

Soekartawi (2006:54) mendefinisikan penerimaan usahatani adalah perkalian antara produksi yang diperoleh dengan harga jual. Menurut Lincolin A. (2008:59), bahwa laba total adalah selisih antara penerimaan total (total revenue $=\mathrm{TR}$ ) dengan jumlah semua biaya $($ total cost $=$ TC), atau Laba total $=\Pi=\mathrm{TR}-\mathrm{TC}$.

Faktor internal yang dapat meningkatkan produksi dan produktivitas serta pendapatan petani padi sawah, yaitu menyangkut identitas yang dimiliki oleh para petani baik yang meliputi pendidikan, umur, luas lahan garapan, jumlah tanggungan keluarga, dan pengalaman berusahatani serta status sosial. Faktor internal tersebut sejalan dengan yang dikemukakan oleh Fallo, Tenaya dan Agung (2018: 64) bahwa upaya peningkatan produksi padi sawah dipengaruhi oleh berbagai faktor di antaranya faktor produksi, lingkungan, serta faktor sosial ekonomi.

Menurut Veithzal Rivai dan Deddy Mulyadi (2010: 231-232) bahwa karakter biografis merupakan karakteristik pribadi yang terdiri dari:

a. Usia

Ada suatu keyakinan yang meluas bahwa produktivitas merosot sejalan dengan makin tuanya usia seseorang. Tetapi hal itu tidak terbukti, karena banyak orang yang sudah tua tapi masih energik. Memang diakui bahwa pada usia muda seseorang lebih produktif dibandingkan ketika usia tua.

\section{b. Jenis Kelamin}

Ada pendapat yang mengatakan bahwa ada perbedaan antara pria dan wanita yang mempengaruhi kinerja, ada juga yang berpendapat tidak ada perbedaan yang konsisten antara pria dan wanita dalam kemampuan memecahkan masalah, keterampilan analisis, dorongan kompetitif, motivasi, sosiabilitas atau kemampuan belajar. Dalam hal ini diasumsikan bahwa tidak ada perbedaan yang berarti dalam hal produktivitas antara pria dan wanita.

\section{c. Status Perkawinan}

Perkawinan biasanya akan meningkatkan rasa tanggung jawab seorang karyawan terhadap pekerjaan yang menjadi tanggung jawabnya, karena pekerjaan nilainya lebih berharga dan penting karena bertambahnya tanggung jawab pada keluarga, dan biasanya karyawan yang sudah menikah lebih puas dengan pekerjaan mereka disbanding dengan yang belum menikah.

\section{d. Masa Kerja}

Masa kerja yang lebih lama menunjukkan pengalaman yang lebih seseorang dibandingkan dengan rekan kerjanya yang lain, sehingga sering masa kerja/pengalaman kerja menjadi pertimbangan sebuah perusahaan dalam mencari pekerja.

Beberapa aspek yang mempengaruhi petani dalam mengelola usahataninya yakni: umur, tingkat pendidikan, pengalaman berusahatani, jumlah anggota keluarga dan luas lahan garapan. Berdasarkan uraian tersebut, maka peneliti tertarik untuk mempelajari faktor-faktor 
internal berupa identitas petani yang mempengaruhi pendapatan bagi usahatani padi sawah yang berada di Kelurahan Ngkaringkaring Kecamatan Bungi Kota Baubau, untuk mendapatkan gambaran yang jelas tentang seberapa besar pengaruh identitas petani dapat mempengaruhi pendapatan dari usahatani padi sawah tersebut.

Berdasarkan latar belakang dan rumusan masalah tersebut di atas, maka tujuan penelitian ini adalah:

1. Untuk membuktikan secara empiris apakah terdapat pengaruh umur petani terhadap pendapatan usahatani padi sawah di Kelurahan Ngkaringkaring Kecamatan Bungi Kota Baubau.

2. Untuk membuktikan secara empiris apakah terdapat pengaruh tingkat pendidikan petani terhadap pendapatan usahatani padi sawah di Kelurahan Ngkaringkaring Kecamatan Bungi Kota Baubau.

3. Untuk membuktikan secara empiris apakah terdapat pengaruh jumlah tanggungan keluarga petani terhadap pendapatan usahatani padi sawah di Kelurahan Ngkaringkaring Kecamatan Bungi Kota Baubau.

4. Untuk membuktikan secara empiris apakah terdapat pengaruh pengalaman berusahatani petani terhadap pendapatan usahatani padi sawah di Kelurahan Ngkaringkaring Kecamatan Bungi Kota Baubau

5. Untuk membuktikan secara empiris apakah terdapat pengaruh luas lahan garapan petani terhadap pendapatan usahatani padi sawah di Kelurahan Ngkaringkaring Kecamatan Bungi Kota Baubau.

6. Untuk membuktikan secara empiris apakah terdapat pengaruh status sosial petani terhadap pendapatan usahatani padi sawah di Kelurahan Ngkaringkaring Kecamatan Bungi Kota Baubau.

Adapun hiopotesis dari penelitian ini adalah:

$\mathrm{H} 1$ = Ada pengaruh positif yang signifikan antara umur petani terhadap pendapatan usahatani padi sawah di Kelurahan Ngkaringkaring Kecamatan Bungi Kota Baubau.

$\mathrm{H} 2$ = Ada pengaruh positif yang signifikan antara tingkat pendidikan petani terhadap pendapatan usahatani padi sawah di Kelurahan Ngkaringkaring Kecamatan Bungi Kota Baubau.

$\mathrm{H} 3$ = Ada pengaruh positif yang signifikan antara jumlah tanggungan keluarga petani terhadap pendapatan usahatani padi sawah di Kelurahan Ngkaringkaring Kecamatan Bungi Kota Baubau.

H4 = Ada pengaruh positif yang signifikan antara pengalaman berusahatani petani terhadap pendapatan usahatani padi sawah di Kelurahan Ngkaringkaring Kecamatan Bungi Kota Baubau. 
H5 = Ada pengaruh positif yang signifikan antara luas lahan garapan petani terhadap pendapatan usahatani padi sawah di Kelurahan Ngkaringkaring Kecamatan Bungi Kota Baubau.

H6 = Ada pengaruh positif yang signifikan antara status sosial petani terhadap pendapatan usahatani padi sawah di Kelurahan Ngkaringkaring Kecamatan Bungi Kota Baubau.

\section{METODE PENELITIAN}

Penelitian ini dilaksanakan di Kelurahan Ngkaringkaring Kecamatan Bungi Kota Baubau, yang berlangsung dari bulan Agustus sampai bulan Oktober Tahun 2019. Populasi dalam penelitian ini adalah keseluruhan petani yang ada di Kelurahan Ngkaringkaring Kecamatan Bungi Kota Baubau yang berjumlah 420 orang atau kepala keluarga (KK).

Penentuan sampel dilakukan dengan menggunakan metode acak sederhana (simple random sampling) pada sejumlah petani padi sawah yang ada di Kelurahan Ngkaringkaring tersebut. dengan mengambil sekitar $10 \%$ yaitu 42 orang petani yang mengusahakan agribisnis padi sawah sebagai responden. Hal ini sesuai dengan pendapat Suharsimi A. (2012) bahwa di dalam buku statistik kadang-kadang terdapat rumus untuk menentukan perkiraan besarnya sampel. Untuk sekedar ancer-ancer maka apabila subyeknya kurang dari 100, lebih baik diambil semua sehingga penelitiannya merupakan penelitian populasi. Selanjutnya jika jumlah subyeknya besar dapat diambil antara $10-15 \%$, atau $20-25 \%$ atau lebih.

Teknik analisis data yang digunakan dalam penelitian ini baik data primer maupun data sekunder akan diolah dan dianalisis secara deskriptif kualitatif dan kuantitatif. Analisis deskriptif kualitatif digunakan untuk menguraikan tentang karakteristik petani responden dan usahataninya. Sedangkan analisis deskriptif kuantitatif digunakan:

1. Untuk mengetahui tingkat pendapatan dengan rumus (Soeharjo dan Dahlan Patong, 1984) :

$\mathrm{NI}=\mathrm{TR}-\mathrm{TC}$

$\mathrm{TR}=\mathrm{P} \times \mathrm{Q}$

$\mathrm{TC}=\mathrm{TFC}+\mathrm{TVC}$

Keterangan :

$\begin{array}{lll}\mathrm{NI} & = & \text { Net Income }(\text { Pendapatan Bersih) }(\mathrm{Rp} / \mathrm{ha}) \\ \mathrm{TR} & = & \text { Total Revenue }(\text { Penerimaan Total })(\mathrm{Rp} / \mathrm{ha}) \\ \mathrm{TC} & = & \text { Total Cost }(\text { Biaya Total })(\mathrm{Rp} / \mathrm{ha}) . \\ \mathrm{P} & = & \text { Price }(\text { Harga Jual Produksi) }(\mathrm{Rp} / \mathrm{kg}) . \\ \mathrm{Q} & = & \text { Kuantitas }(J u m l a h \text { Produksi) }(\mathrm{kg} / \mathrm{ha}) . \\ \mathrm{TFC} & = & \text { Total Fixed Cost }(\text { Biaya Tetap Total })(\mathrm{Rp} / \mathrm{thn}) .\end{array}$


TVC $=\quad$ Total Variable Cost (Biaya Variabel Total) $(\mathrm{Rp} / \mathrm{thn})$.

Untuk melihat pengaruh vaiabel $\mathrm{X}$ dan variabel Y dengan menggunakan analisis regresi linear berganda dengan persamaan sebagai berikut:

Persamaan I

$\tilde{Y} 1=a+b 1 X 1+b 2 X 2+b 3 X 3+b 4 X 4+b 5 X 5+b 6 D 1+\varepsilon$

Persamaan II

$\tilde{\mathrm{Y}} 2=\mathrm{a}+\mathrm{b} 1 \mathrm{X} 1+\mathrm{b} 2 \mathrm{X} 2+\mathrm{b} 3 \mathrm{X} 3+\mathrm{b} 4 \mathrm{X} 4+\mathrm{b} 5 \mathrm{X} 5+\mathrm{b} 6 \mathrm{D} 1+\varepsilon$

Keterangan:

$\tilde{\mathrm{Y}} 1=$ Produktivitas Petani Agribisnis Padi Sawah $(\mathrm{kg} / \mathrm{ha})$ dan

$\tilde{\mathrm{Y}} 2=$ Pendapatan Petani Agribisnis Padi Sawah (Rp/ha).

$\mathrm{X} 1=$ Umur Petani Agribisnis Padi Sawah (tahun)

$\mathrm{X} 2=$ Tingkat Pendidikan Petani Agribisnis Padi Sawah (tahun)

$\mathrm{X} 3=$ Jumlah Tanggungan Keluarga Petani Agribisnis Padi Sawah (orang)

$\mathrm{X} 4=$ Pengalaman Berusahatani Petani Agribisnis Padi Sawah (tahun)

X5 = Luas Lahan Garapan Petani Agribisnis Padi Sawah (ha)

$\mathrm{D} 1=$ Variabel dummy status sosial $(\mathrm{D} 1=1$ tinggi; $\mathrm{D} 1=0$ rendah $)$

Dalam analisa regresi berganda, pengujian hipotesis dapat dilakukan terhadap masingmasing koefisien regresi (bi) secara individual/terpisah, dan juga dapat dilakukan secara bersamaan. Untuk pengujian secara individual dilakukan uji dengan sebaran statistik t, tetapi dalam pengujian serentak atau bersamaan dilakukan dengan uji sebaran statistik F. Adapun hipotesis pada pengujian individual yaitu:

$$
\begin{array}{ll}
- & \mathrm{H} 0: \beta=0 \\
- & \mathrm{H} 1: \beta>0
\end{array}
$$

Titik kritis dalam pengujian ini adalah $\mathrm{t} \alpha(\mathrm{db})$

Kriteria pengujian:

- $\quad$ Jika t hitung $\geq \mathrm{t} \alpha(\mathrm{db})$ pada taraf kepercayaan $95 \%(\alpha=0.05)$, berarti tolak H0 atau terima $\mathrm{H} 1$ artinya ada pengaruh identitas petani terhadap produktivitas maupun pendapatan usahatani padi sawah di Kelurahan Ngkaringkaring Kecamatan Bungi Kota Baubau.

- $\quad$ Jika thitung $<\mathrm{t} \alpha(\mathrm{db})$ pada taraf kepercayaan $95 \%(\alpha=0.05)$, berarti terima H0 atau tolak H1 artinya tidak ada pengaruh identitas petani terhadap produktivitas maupun pendapatan usahatani padi sawah di Kelurahan Ngkaringkaring Kecamatan Bungi Kota Baubau. 
Rumus untuk mencari thitung adalah:

$$
\begin{array}{r}
\text { bi }-\beta \mathrm{i} 0 \\
\mathrm{t} \text { hitung }=
\end{array}
$$

Sbi

Untuk mengetahui konstribusi pengaruh antara variable independen (X) terhadap variable dependen (Y) maka digunakan koefisien determinasi R2, dimana nilai R2 berkisar antara 0 sampai dengan 1 . Dengan ketentuan:

- $\quad$ Jika semua variasi dalam Y dapat dijelaskan oleh variasi dalam X maka R2 = 1

- $\quad$ Jika variasi X tidak dapat menjelaskan variasi Y sama sekali maka nilai R2 $=0$

(Departemen Pendidikan dan Kebudayaan, 1999).

Keterangan: Perhitungan analisis linear berganda dengan menggunakan program yang di kenal dengan nama Statistical Package for the Social Sciences atau Statistical Product and Service Solutions (SPSS) versi 19,0.

Menurut Singgih S. (2002:382) bahwa uji t digunakan untuk menguji signifikansi konstanta dan variable dependen. Berdasarkan probabilitas yaitu:

- $\quad$ Jika probabilitas $>0,05$, H0 diterima.

- $\quad$ Jika probabilitas $<0,05$, H0 ditolak.

Kriteria tersebut sejalan dengan kriteria pengujian $t$ pada taraf kepercayaan 95\% sebelumnya dan kedua kriteria tersebut hanya untuk memudahkan ketika membaca hasil output dari analisis program SPSS versi 19,0

\section{HASIL DAN PEMBAHASAN}

\section{Identitas Petani Responden}

Identitas responden merupakan keadaan dari petani padi sawah yang dapat menunjang dalam melakukan aktivitas usahanya, dimana latar belakang responden yang diteliti tersebut akan menentukan suatu perubahan variabel dalam penelitian. Adapun identitas responden meliputi umur, tingkat pendidikan, jumlah tanggungan keluarga, dan pengalaman berusahatani, luas lahan garapan dan status sosial yang dapat diuraikan sebagai berikut:

a. $\mathrm{Um} \mathrm{u} \mathrm{r}$

Umur seseorang akan mempengaruhi kemampuannya dalam mengolah usahataninya baik kemampuan fisik maupun pikirannya dalam bekerja. Petani yang berusia relatif muda akan memiliki kemampuan yang lebih baik dalam mengerjakan pekerjaan-pekerjaan fisik dibandingkan dengan petani berumur tua. 
Secara umum, umur seseorang digolongkan ke dalam usia produktif dan non produktif yang didasarkan pada kondisi atau kemampuan fisik seseorang dalam berusaha dari jenis pekerjaan yang digelutinya. Menurut Soeharjo dan Patong (1984) bahwa umur produktif manusia berkisar antara 15 sampai 54 tahun, sedangkan yang non produktif di atas 54 tahun atau di bawah 15 tahun. Untuk lebih jelasnya mengenai umur petani responden disajikan dalam Tabel 2.

Tabel 2. Klasifikasi Umur Responden di Kelurahan Ngkaringkaring Kecamatan Bungi Kota Baubau Tahun 2019

\begin{tabular}{llll}
\hline No. & $\begin{array}{l}\text { Klasifikasi Umur } \\
\text { (tahun) }\end{array}$ & $\begin{array}{l}\text { Responden } \\
\text { (orang) }\end{array}$ & $\begin{array}{l}\text { Persentase } \\
(\%)\end{array}$ \\
\hline 1. & $25-54$ & 34 & 80,95 \\
$2 . \quad$ & $\geq 55$ & 8 & 19,05 \\
\hline & Jumlah & 42 & 100,00 \\
\hline
\end{tabular}

Sumber: Data Primer Diolah Tahun 2019

Berdasarkan Tabel 2, dapat dijelaskan bahwa sebagian besar responden termasuk golongan usia produktif yaitu 34 orang atau $80,95 \%$, hal ini sangat baik terutama dalam hal berusahatani, karena merupakan peluang untuk meningkatkan produksi usahataninya utamanya padi sawah dan sekaligus dalam meningkatkan dan mempertahankan mutu produksinya.

\section{b. Pendidikan}

Pendidikan adalah merupakan upaya dalam membangun sumber daya manusia yang berkualitas, karena pendidikan akan mempengaruhi pola pikir, sikap maupun cara bertindak seseorang dalam menyelesaikan berbagai persoalan yang dihadapinya terutama dalam menjalankan usahanya. Disamping itu pendidikan juga dapat memudahkan para petani dalam menerima informasi dan adopsi inovasi baru khususnya mengenai teknologi pertanian. Untuk lebih jelasnya mengenai keadaan pendidikan petani responden disajikan pada Tabel 3.

Tabel 3. Tingkat Pendidikan Responden di Kelurahan Ngkaringkaring Kecamatan Bungi Kota Baubau Tahun 2019

\begin{tabular}{llll}
\hline No. & Tingkat Pendidikan Formal & $\begin{array}{l}\text { Responden } \\
\text { (orang) }\end{array}$ & $\begin{array}{l}\text { Persentase } \\
(\%)\end{array}$ \\
\hline 1. & Tamat SD & 23 & 54,76 \\
2. & Tamat SMP & 6 & 14,29 \\
3. & Tamat SMA & 12 & 28,57 \\
\hline
\end{tabular}




\begin{tabular}{|c|c|c|c|}
\hline 4. & Tamat Perguruan Tinggi (S1) & 1 & 2,38 \\
\hline & Jumlah & 42 & 100,00 \\
\hline
\end{tabular}

\section{Sumber: Data Primer Diolah Tahun 2019}

Berdasarkan Tabel 3, menunjukkan bahwa para petani responden memiliki tingkat pendidikan formal yang dapat dikatakan memadai, walaupun sebagian besar pendidikannya adalah ditingkat SD, namun karena sudah memiliki pengetahuan dasar untuk menulis dan membaca, hal ini sangat membantu dalam menerima informasi yang menyangkut usahatani yang mereka usahakan, karena tingkat pendidikan akan mempengaruhi pola pikir dari petani responden tersebut dalam hal pengambilan keputusan yang berhubungan dengan kegiatan usahataninya. Sedangkan untuk mengatasi pendidikan petani responden yang masih kurang, perlu adanya pembinaan lebih lanjut secara intensif melalui kegiatan pelatihan maupun diberikan penyuluhan oleh pihak Penyuluh Pertanian Lapangan (PPL) untuk menambah wawasan dan pengetahuan para petani, sehingga mereka dapat berkembang menjadi petani yang profesional dan produktif, disamping itu pula media tersebut sangat dibutuhkan oleh para petani yang tergabung dalam kelompok tani, sebagai media dalam menyampaikan segala permasalahan yang mereka hadapi guna mencari alternatif pemecahannya.

\section{c. Jumlah Tanggungan Keluarga}

Tanggungan keluarga adalah semua orang yang tinggal dalam satu keluarga petani yang secara langsung merupakan tanggungan keluarga petani atau tidak tinggal dalam satu keluarga tetapi masih di tanggung oleh petani tersebut karena salah satu faktor adalah anak keluarga petani tersebut ingin melanjutkan pendidikan.

Jumlah tanggungan keluarga yang besar ditinjau dari segi sosial ekonomi tentu akan memberatkan, namun jika ditinjau dari penggunaan tenaga kerja akan sangat menguntungkan dalam menjalankan usahanya, sebab dengan banyaknya tanggungan keluarga apalagi berada pada usia produktif, maka akan memberikan kelancaran bagi kegiatan usahatani petani tersebut. Disamping itu makin besar jumlah tanggungan keluarga, maka makin besar pula jumlah kebutuhan yang harus dipenuhi oleh kepala keluarga, sehingga petani di tuntut agar lebih giat bekerja untuk memenuhi kebutuhan hidupnya berserta keluarganya. Untuk lebih jelasnya mengenai keadaan jumlah tanggungan keluarga petani responden disajikan dalam Tabel 4.

Tabel 4. Keadaan Petani Responden Berdasarkan Jumlah Tanggungan Keluarga di Kelurahan Ngkaringkaring Tahun 2019

\begin{tabular}{llll}
\hline No. & $\begin{array}{l}\text { Jumlah Tangungan Keluarga } \\
\text { (orang) }\end{array}$ & $\begin{array}{l}\text { Jumlah } \\
\text { (orang) }\end{array}$ & $\begin{array}{l}\text { Persentase } \\
(\%)\end{array}$ \\
\hline 1. & $1-4$ & 31 & 73,81 \\
2. & $5-8$ & 11 & 26,19 \\
\hline
\end{tabular}


Berdasarkan Tabel 4, dapat dijelaskan bahwa responden yang memiliki jumlah tanggungan keluarga 1-4 yaitu berjumlah 31 orang atau 73,81\% lebih besar dibandingkan dengan responden yang memiliki jumlah tanggungan keluarga 5-8 orang yaitu berjumlah 11 orang atau $26,19 \%$.

Dari kenyataan tersebut terlihat jelas bahwa persediaan tenaga kerja dalam keluarga responden yaitu sebagian besar sangat memadai jika sebagian besar dari jumlah tanggungan keluarga tersebut tergolong dalam usia produktif dan ikut berperan dalam upaya meningkatkan pendapatan keluarga. Namun apabila jumlah tanggungan keluarga yang termasuk dalam golongan usia tidak produktif lebih besar, maka akan berpengaruh kurang baik terhadap tingkat pendapatan yang diperoleh dan konsumsi kebutuhan keluarga responden akan semakin besar.

\section{d. Pengalaman Berusahatani}

Pengalaman merupakan guru yang paling baik dan sekaligus menjadi acuan bagi seseorang dalam melakukan suatu kegiatan atau pekerjaan. Bagi seorang petani apa yang telah dilakukan selama berusahatani merupakan suatu pengalaman yang sangat berharga sekaligus sebagai modal dimasa yang akan datang.

Pengalaman berusahatani seorang petani responden adalah juga merupakan proses pendidikan yang diperoleh dari luar bangku sekolah. Pengalaman berusahatani akan selalu membawa perubahan bagi petani dalam mengelolah usahataninya. Petani dengan pengalaman yang banyak diharapkan dapat menentukan alternative yang lebih baik sehubungan dengan usahataninya. Pengalaman yang tinggi dapat memberikan suatu pelajaran yang bermanfaat, sebab petani dapat belajar dari kesalahan yang pernah terjadi pada dirinya sehingga dapat dijadikan pedoman dalam merubah kebiasaan-kebiasaan yang buruk kearah yang lebih baik, dimasa-masa yang akan datang (proses evaluasi diri).

Pengalaman berusahatani dapat dikatakan cukup berpengalaman, apabila menggeluti bidang pekerjaannya selama 5-10 tahun. Sedangkan 10 tahun ke atas dikategorikan berpengalaman dan lebih kecil dari 5 tahun dikategorikan kurang berpengalaman (Soeharjo dan Dahlan Patong, 1984).

Untuk lebih jelas mengenai pengalaman berusahatani responden disajikan dalam Tabel 5.

Tabel 5. Keadaan Petani Responden Berdasarkan Pengalaman Berusahatani di Kelurahan Ngkaringkaring Kecamatan Bungi Kota Baubau Tahun 2019

\begin{tabular}{llll}
\hline No. & $\begin{array}{l}\text { Pengalaman Berusahatani } \\
\text { (tahun) }\end{array}$ & $\begin{array}{l}\text { Jumlah } \\
\text { (orang) }\end{array}$ & $\begin{array}{l}\text { Persentase } \\
(\%)\end{array}$ \\
\hline 1. & $6-19$ & 20 & 47,62
\end{tabular}




\begin{tabular}{llll}
\hline 2. & $20-33$ & 19 & 45,24 \\
3. & $34-47$ & 3 & 7,14 \\
\hline & Jumlah & 42 & 100 \\
\hline
\end{tabular}

Sumber: Data Primer Diolah Tahun 2019

Dari Tabel 5 nampak bahwa rata-rata petani responden di Kelurahan Ngkaringkaring telah memiliki pengalaman yang cukup memadai karena rata-rata petani responden telah berusahatani antara 15 sampai 45 tahun, sehingga sebagaimana yang dikemukakan oleh Soeharjo dan Patong (1984:30) bahwa seseorang dapat melakukan aktivitas usahataninya dengan baik apabila telah memiliki pengalaman antara 10 sampai dengan 20 tahun.

Berdasarkan kondisi tersebut dapat dikatakan bahwa pengalaman dalam berusahatani bagi petani yang ada di Kelurahan Ngkaringkaring sebagian besar dikategorikan berpengalaman dalam mengelolah usahataninya. Yang pada akhirnya dapat meningkatkan produksi usahataninya.

\section{e. Luas Lahan Garapan}

Luas lahan garapan yang dimaksud dalam penelitian ini adalah lahan yang digunakan oleh petani responden dalam mengusahakan tanaman padi sawah. Luas lahan garapan yang dimiliki oleh petani berhubungan dengan besarnya biaya usaha tani yang harus dikeluarkan dan jumlah pekerja yang dilibatkan didalamnya. Luas lahan garapan yang dapat diusahakan oleh petani akan menentukan besarnya produk yang akan dihasilkan. Makin luas lahan garapan yang dimiliki oleh petani, maka makin bebas petani tersebut dalam mengelola lahan untuk diusahakan. Untuk mengetahui keadaan petani responden di Kelurahan Ngkaringkaring berdasarkan luas lahan garapan dapat dilihat pada Tabel 6. sebagai berikut:

Tabel 6. Keadaan Petani Responden Menurut Luas Lahan Garapan di Kelurahan Ngkaringkaring Kecamatan Bungi Tahun 2019

\begin{tabular}{llll}
\hline No. & Luas Lahan Petani Responden & Jumlah & Persentase \\
& $(\mathrm{Ha})$ & (orang) & $(\%)$ \\
\hline 1. & $0,5-1,0$ & 29 & 69,05 \\
2. & $1,5-2,0$ & 13 & 30,95 \\
\hline & Jumlah & 42 & 100,00 \\
\hline
\end{tabular}

Sumber: Data Primer Diolah Tahun 2019

Berdasarkan Tabel 6, nampak bahwa luas lahan garapan yang dimiliki petani responden antara $0,5-1,0 \mathrm{Ha}$. sebanyak 29 orang petani $(69.05 \%)$, sedangkan yang memiliki luas lahan 1,5-2,0 Ha sebanyak 13 orang (30,95\%). Hal ini menunjukkan bahwa petani responden telah memiliki lahan yang cukup luas dalam hal ini akan berpengaruh terhadap 
tenaga kerja, sarana produksi maupun teknologi yang digunakan. Sedangkan luas lahan yang diusahakan dengan teknologi sederhana, maka penggunaan tenaga kerja akan semakin banyak, juga membutuhkan sarana produksi yang besar.

\section{f. Status Sosial}

Status sosial petani adalah status lain yang dimiliki oleh petani responden selain sebagai petani, yang tentunya status sosial tersebut lebih bersentuhan langsung dengan kegiatan usahatani yang sedang dijalankan seperti yang dikenal dengan penyubaktian (Seke Subak) pada masyarakat Bali yang ada di Ngkaringkaring. Di Ngkaringkaring terdapat 2 Subak yaitu Bali Sari dan Wana Sari. Seperti yang telah dijelaskan oleh Grader (1960) dalam I Gede Suyatna (1982:3) menyatakan bahwa ada dua kewajiban utama Subak yaitu pekaryaan dan penyubaktian. Pekaryaan merupakan kewajiban di luar agama, antara lain membuat, memelihara dan memperbaiki bendungan, terowongan, saluran air dan juga jalan Subak. Sedangkan penyubaktian merupakan kewajiban yang ada hubungannya dengan keagamaan seperti membuat sesajen dan sembahyang di Pure Subak.

Keberadaan Seke Subak kalau diamati sepintas sama dengan kelompok yang dibuat oleh pemerintah yaitu dengan istilah P3A (Perkumpulan Petani Pemakai Air). Bedanya disini adalah pada Subak mempunyai sifat otonom untuk mengatur kegiatannya yang dibuktikan dengan adanya Awig-Awig atau Peraturan Subak baik Bali sari maupun Wana Sari yang harus ditaati oleh setiap anggotanya, karena merupakan hasil rapat bersama antara Pengurus Subak dan para anggotanya. Melalui kelompok Subak ini masyarakat di Kelurahan Ngkaringkaring, melangsungkan hidupnya dalam hal memenuhi kebutuhan, mengembangkan diri dan mengembangkan potensi serta aktualisasi diri.

Berdasarkan hal tersebut, maka diharapkan Seke Subak diharapkan dapat menjadi kelompok yang mandiri, mampu menampung berbagai aspirasi dari kebutuhan masyarakat, berkembang sebagai organisasi ekonomi pedesaan dan mampu berpartisipasi dalam setiap gerak pembangunan pertanian. Sehubungan dengan itu perlu dilakukan pembinaan dalam rangka penumbuhan dan pengembangan kelompoktani yang telah ada, agar menjadi kelompok yang kuat dan mandiri untuk meningkatkan produktivitas dan pendapatan petani dan keluarganya. Oleh karena itu status sosial seseorang dihitung dengan cara memberi nilai 1 (satu) jika status sosialnya tinggi dalam hal ini jika memegang jabatan dalam kelompok tani/Subak dan aktif dalam setiap kegiatan kelompok, karena diharapkan mampu menerima segala perubahan terutama masalah inovasi teknologi yang sifatnya masih baru dan saai ini pun pemerintah melakukan pendekatan kepada petani melalui kelompok tani yang ada dan nilai 0 (nol) jika status sosialnya rendah yaitu sebagai anggota dan kurang aktif dalam setiap kegiatan usahatani terutama padi sawah. Untuk lebih jelasnya mengenai status sosial petani responden di Kelurahan Ngkaringkaring dapat dilihat pada Tabel 7.

Tabel 7. Keadaan Petani Responden Menurut Status Sosial di Kelurahan Ngkaringkaring Kecamatan Bungi Tahun 2019

\begin{tabular}{llll}
\hline No. & Status Sosial & $\begin{array}{l}\text { Jumlah } \\
(\text { orang) }\end{array}$ & $\begin{array}{l}\text { Persentase } \\
(\boldsymbol{\%})\end{array}$ \\
\hline 1. & Status Sosial Tinggi (1) & 26 & 61,91 \\
\hline
\end{tabular}


Vol. 3, Issue 2, November 2019

P-ISSN: 2527-8479 E-ISSN: 2686-2174

\begin{tabular}{llcl}
\hline 2. & Status Sosial Rendah $(0)$ & 16 & 38,09 \\
\hline Jumlah & $\mathbf{4 2}$ & $\mathbf{1 0 0 , 0 0}$
\end{tabular}

Sumber: Data Primer Diolah Tahun 2019

Berdasarkan Tabel 7, nampak bahwa status sosial dengan kategori tinggi dimiliki oleh petani responden yaitu 26 orang $(61,91 \%)$, sedangkan status sosial dengan kategori rendah yaitu hanya 16 orang $(38,09 \%)$. Tentunya hal ini akan mempengaruhi tingkat produktivitas maupun pendapatan yang berasal dari sektor usahatani khususnya padi sawah, karena yang memiliki status sosial tinggi biasanya lebih dominan dalam setiap kegiatan usahatani yang sedang digelutinya, sedangkan yang dalam kategori status sosialnya rendah biasanya kurang dominan baik dalam kegiatan penyuluhan yang dilakukan oleh PPL maupun kegiatan di dalam kelompok itu sendiri.

\section{Deskripsi Usahatani}

Deskripsi usaha tani merupakan gambaran keadaan usahatani petani responden dalam melakukan kegiatan atau aktifitas usahataninya. Deskripsi usahatani yang dimaksud meliputi status pemilikan lahan, produksi, produktivitas, nilai produksi, biaya produksi dan pendapatan usahatani. Untuk lebih jelasnya mengenai deskripsi usahatani dapat diuraikan sebagai berikut:

\section{a. Status Pemilikan Lahan}

Status pemilikan lahan menunjukkan bahwa apabila lahan tersebut merupakan milik sendiri, atau milik orang lain yang digarap dengan sistem bagi hasil hal ini akan berpengaruh bagi petani responden dalam menentukan besar kecilnya penerimaan dari usahatani yang dijalankan. Namun berdasarkan wawancara dengan para petani responden, maka diperoleh keterangan bahwa areal usahatani yang mereka tanami merupakan milik sendiri, sehingga dalam hal ini tidak ada bagi hasil dengan petani penggarap karena areal usahatani adalah milik sendiri dan sebagian besar dikerjakan sendiri oleh petani yang bersangkutan.

b. Produksi

Produksi yang dimaksud adalah apabila yang sudah diproses menjadi beras yang dihasilkan oleh petani responden dalam jangka waktu satu musim panen. Adapun tingkat produksi beras petani responden di Kelurahan Ngkaringkaring Kecamatan Bungi Kota Baubau dapat dilihat dalam Tabel 8.

Tabel 8. Tingkat Produksi Beras Petani Responden di Kelurahan Ngkaringkaring Kecamatan Bungi Kota Baubau Tahun 2019

\begin{tabular}{|l|l|l|l|}
\hline No. & $\begin{array}{l}\text { Tingkat Produksi Beras } \\
\text { Kg/musim tanam }\end{array}$ & $\begin{array}{l}\text { Jumlah } \\
(\text { orang })\end{array}$ & $\begin{array}{l}\text { Persentase } \\
(\boldsymbol{\%})\end{array}$ \\
\hline 1. & $1200-4600$ & 29 & 69,05 \\
2. & $4601-8001$ & 13 & 30,95 \\
\hline & Jumlah & $\mathbf{4 2}$ & $\mathbf{1 0 0 , 0 0}$ \\
\hline
\end{tabular}


Pada Tabel 8, nampak bahwa jumlah produksi beras di Kelurahan Ngkaringkaring yaitu 1200-4600 Kg berjumlah 29 orang (69,05\%), sedangkan 4601-8001 hanya berjumlah 13 orang $(30,95 \%)$. Kondisi tersebut disebabkan oleh luas lahan garapan petani yang berbedabeda antara petani responden yang satu dengan petani responden yang lain, di samping itu pula tergantung perlakuan yang dikerjakan oleh petani responden terhadap lahan usahataninya, dalam upaya meningkatkan kesuburan tanahnya. Masalah produksi ini menurut wawancara dengan salah satu responden yaitu I Wayan Suwija pada tanggal 23 September 2019 bahwa sebagian dari produksi yang dihasilkan ada yang dijual adapula yang dikonsumsi.

\section{c. Nilai Produksi}

Nilai produksi atau penerimaan yang dimaksud dalam penelitian ini adalah jumlah produksi beras yang dihasilkan (Kg) dikalikan dengan harga jual dalam satu kali masa panen $(\mathrm{Rp} / \mathrm{Kg})$. Untuk lebih jelas mengenai nilai produksi beras yang diperoleh petani responden disajikan pada Tabel 9.

Tabel 9. Nilai Produksi Beras yang Dihasilkan oleh Para Responden yang berada di Kelurahan Ngkaringkaring Kecamatan Bungi Kota Baubau Tahun 2019.

\begin{tabular}{|l|l|l|l|}
\hline No. & $\begin{array}{l}\text { Nilai Produksi } \\
\text { (Rp./musim tanam) }\end{array}$ & $\begin{array}{l}\text { Jumlah } \\
(\text { orang })\end{array}$ & $\begin{array}{l}\text { Persentase } \\
(\%)\end{array}$ \\
\hline 1. & $7.800 .000-31.100 .000$ & 29 & 69,05 \\
2. & $31.100 .001-54.400 .000$ & 13 & 30,95 \\
\hline & Jumlah & $\mathbf{4 2}$ & $\mathbf{1 0 0 , 0 0}$ \\
\hline
\end{tabular}

\section{Sumber: Data Primer Diolah Tahun 2019}

Berdasarkan data pada Tabel 9, nampak bahwa sebagian besar responden memiliki nilai produksi antara Rp. 7.800.000-Rp. 31.100.000/musim tanam yakni sebanyak 29 orang (69,05\%). Sedangkan yang memiliki pendapatan Rp. 31.100.001 - Rp. 54.400 .000 sebanyak 13 orang $(30,95 \%)$. Jadi besar kecilnya produksi yang dicapai tergantung dari input yang diberikan dalam berusahatani dan ada tidaknya serangan hama dan penyakit tanaman, karena menurut wawancara dengan Made Swena pada tanggal 22 Desember 2011, banyaknya serangan hama pada priode panen musim tanam tahun ini yaitu hama tikus, walang sangi, penggerek batang, belum lagi kehilangan produksi pada saat proses pemanenan dan perontokan padi, pada saat pengangkutan, proses penjemuran, dimakan hewan peliharaan maupun proses penggilingan padi.

\section{e. Biaya Produksi}

Biaya produksi adalah semua pengeluaran yang dikeluarkan oleh petani untuk keperluan usahatani yang dinilai dengan uang (rupiah). Biaya produksi yang dimaksud dalam 
penelitian ini adalah keseluruhan biaya yang dikeluarkan oleh petani selama melakukan kegiatan usahataninya, baik biaya tetap, biaya variabel maupun penyusutan alat. Untuk lebih jelas mengenai biaya yang dikeluarkan petani responden padi sawah dapat dilihat dalam Tabel 10.

Tabel 10. Biaya Produksi yang dikeluarkan oleh Petani Responden Selama 1 Masa Tanam di Kelurahan Ngkaringkaring Kecamatan Bungi Kota Baubau Tahun 2019

\begin{tabular}{|l|l|l|l|}
\hline No. & $\begin{array}{l}\text { Total Biaya Produksi } \\
(\mathrm{Rp})\end{array}$ & $\begin{array}{l}\text { Jumlah } \\
(\text { orang })\end{array}$ & $\begin{array}{l}\text { Perasentase } \\
(\%)\end{array}$ \\
\hline 1. & $265.000-2.782 .500$ & 29 & 69,05 \\
2. & $2.782 .501-5.300 .000$ & 13 & 30,95 \\
\hline & Jumlah & $\mathbf{4 2}$ & $\mathbf{1 0 0 , 0 0}$ \\
\hline
\end{tabular}

Sumber: Data Primer Diolah Tahun 2019

Dari tabel tersebut di atas nampak bahwa sebagian besar petani responden yaitu 29 orang atau 69,05\% memiliki biaya produksi antara Rp. 265.000- Rp.2.782.500 dan selebihnya 13 orang atau 30,95\% berkisar antara Rp. 2.782.501- Rp. 5.300.000. Hal ini menunjukkan bahwa besar kecilnya biaya yang diperoleh akan mempengaruhi net income yang dihasilkan dalam 1 musim tanam pada tanaman padi sawah tersebut.

f. Pendapatan

Pendapatan yang diperoleh petani responden dalam penelitian ini yaitu penerimaan dikurangi biaya produksi yang digunakan selama musim tanam. Untuk lebih jelasnya mengenai pendapatan petani responden disajikan dalam Tabel 11.

Tabel 11. Keadaan Petani Responden Berdasarkan Tingkat Pendapatan di Kelurahan Ngkaringkaring Kecamatan Bungi Kota Baubau Tahun 2019

\begin{tabular}{|l|l|l|l|}
\hline No. & $\begin{array}{l}\text { Tingkat Pendapatan Usahatani Padi Sawah } \\
\text { (Rp./musim tanam) }\end{array}$ & $\begin{array}{l}\text { Jumlah } \\
\text { (orang) }\end{array}$ & $\begin{array}{l}\text { Persentase } \\
(\boldsymbol{\%})\end{array}$ \\
\hline 1. & $6.600 .000-27.855 .000$ & 31 & 73,81 \\
2. & $27.855 .001-49.110 .000$ & 11 & 26,19 \\
\hline & Jumlah & $\mathbf{4 2}$ & $\mathbf{1 0 0 , 0 0}$ \\
\hline
\end{tabular}

Sumber: Data Primer Diolah Tahun 2019

Dari Tabel 11. di atas nampak bahwa petani responden memiliki pendapatan bersih dari usahatani padi sawah adalah antara Rp.6.600.000- Rp.49.110.000/musim tanam. Hal ini menunjukkan bahwa pemenuhan kebutuhan minimum sehari-hari lebih dari cukup.

3. Analisis Pengaruh Identitas Petani Terhadap Pendapatan Pada Usahatani Padi Sawah 
Berdasarkan hasil pengolahan data komputer yang di kelola oleh komputer dengan program SPSS Versi 19,0, maka analisis pengaruh identitas petani (umur, tingkat pendidikan, pengalaman berusahatani, jumlah tanggungan keluarga, luas lahan garapan serta status sosial, terhadap pendapatan dianalisis dengan menggunakan analisis regresi linear berganda (lebih dari dua variable bebas). Hasil analisis tersebut digunakan untuk menguji H1, H2, H3, H4, H5 dan H6.

Analisis regresi linear berganda (lebih dari dua variable bebas), dalam melihat koefisien determinasinya akan menggunakan Adjusted R Square dengan nilai 0,946, semakain tinggi nilai Adjusted R Square dalam hal ini mendekati angka 1 (satu), maka semakin baik bagi model regresi, karena variable bebas baik X1-X6 bisa menjelaskan variable tidak bebas lebih besar. Untuk lebih jelasnya mengenai Adjusted R Square dapat dilihat pada Tabel 12.

Tabel 12. Model Summary ${ }^{b}$ Untuk Melihat Nilai Adjusted $\mathbf{R}^{2}$ Pada Pengaruh Identitas Petani dengan Pendapatan

\begin{tabular}{|l|l|l|l|l|}
\hline Model & $R$ & R Square & Adjusted R Square & Std. Error of the Estimate \\
\hline 1 & $.984^{\mathrm{a}}$ & .969 & .964 & 2261769.794 \\
\hline
\end{tabular}

a. Predictors: (Constant), Status, Pengalaman, Tanggungan, Lahan, Pendidikan, Umur

Angka Adjusted R Square dengan nilai 0,964 jika dikali 100\% akan menjadi 96,4\% dalam hal ini berarti variasi pendapatan, bisa dijelaskan oleh variabel umur, tingkat pendidikan, pengalaman berusahatani, jumlah tanggungan keluarga, luas lahan garapan serta status sosial, sedangkan sisanya $(100 \%-96,4 \%=3,6 \%$ di jelaskan oleh faktor-faktor yang lain. Dengan demikian dapat dikatakan bahwa identitas petani secara bersama-sama memberikan konstribusi pengaruh yang kuat terhadap produktivitas pada usahatani padi sawah di Kelurahan Ngkaringkaring sebesar 96,4\%.

Untuk melihat tabel persamaan regresi, t hitung serta tingkat signifikance maka dapat dilihat pada Tabel 13. berikut:

Tabel 13. Coefficientsa Untuk Melihat Persaman Regresi, t hitung dan Kisaran Nilai Sig. Faktor Identitas Petani Terhadap Pendapatan di Kelurahan Ngkaringkaring Tahun 2019

Tabel 13. Coefficients ${ }^{a}$ Untuk Melihat Persaman Regresi, $t$ hitung dan Kisaran Nilai Sig. Faktor Identitas Petani Terhadap Pendapatan di Kelurahan Ngkaringkaring Tahun 2019

\begin{tabular}{|l|l|l|l|l|l|l|}
\hline \multirow{2}{*}{ Model } & \multicolumn{2}{|l|}{$\begin{array}{l}\text { Unstandardized } \\
\text { Coefficients }\end{array}$} & $\begin{array}{l}\text { Standardized } \\
\text { Coefficients }\end{array}$ \\
\cline { 2 - 4 } & $\mathrm{B}$ & Std. Error & Beta & Sig. & Penjelasan \\
\hline
\end{tabular}




\begin{tabular}{|c|c|c|c|c|c|c|}
\hline 1 (Constant) & $\begin{array}{l}- \\
17847971.470\end{array}$ & $\begin{array}{l}2583441.15 \\
9\end{array}$ & & -6.909 & .000 & \\
\hline Umur & 28087.682 & 59513.566 & .027 & .472 & .640 & $\begin{array}{l}\text { Tidak } \\
\text { Berpengaruh }\end{array}$ \\
\hline Pendidikan & 852974.883 & 187292.426 & .209 & 4.554 & .000 & Berpengaruh \\
\hline Pengalaman & -27355.536 & 62873.537 & -.025 & -.435 & .666 & $\begin{array}{l}\text { Tidak } \\
\text { Berpengaruh }\end{array}$ \\
\hline Tanggungan & 150956.487 & 266211.598 & .019 & .567 & .574 & $\begin{array}{l}\text { Tidak } \\
\text { Berpengaruh }\end{array}$ \\
\hline Lahan & 25524589.636 & 971962.393 & .933 & $\begin{array}{l}26.26 \\
1\end{array}$ & .000 & Berpengaruh \\
\hline Status & 514627.937 & $\begin{array}{l}1115969.86 \\
8\end{array}$ & .021 & .461 & .648 & $\begin{array}{l}\text { Tidak } \\
\text { Berpengaruh }\end{array}$ \\
\hline
\end{tabular}

a. Dependent Variable: Pendapatan

Tabel 13. menunjukkan persamaan regresi antara variabel dependent dengan variabel independent sebagai berikut:

$\mathrm{Y} 1=-17847971,470+28087,682 \mathrm{X} 1+852974.883 \mathrm{X} 2-27355.536 \mathrm{X} 3+150956.487 \mathrm{X} 4$ +25524589.636 X5 + 514627.937 X6

Keterangan:

$\mathrm{Y} \quad=$ Produktivitas $(\mathrm{Kg} / \mathrm{Ha})$

$\mathrm{X} 1=$ Umur (tahun)

$\mathrm{X} 2=$ Pendidikan

X3 = Pengalaman Berusahatani (tahun)

X4 = Jumlah Tanggungan Keluarga (orang)

X5 = Luas Lahan Garapan (Ha)

X6 = Status Sosial

Berdasarkan persamaan regresi tersebut, maka nilai konstanta sebesar

-17847971,470 menyatakan bahwa, jika tidak ada umur, tingkat pendidikan, pengalaman berusahatani, jumlah tanggungan keluarga, luas lahan garapan serta status sosial, maka pendapatan usahatani padi sawah tersebut adalah sebesar Rp. -17847971,470. Sedangkan koefisien regresi sebesar 28087,682 menyatakan bahwa setiap penambahan (karena tanda + ) 1 tahun umur petani padi sawah, akan meningkatkan pendapatan sebesar Rp. 28087,682. 
Koefisien regresi X2 sebesar 852974.883 menyatakan bahwa setiap penambahan (karena tanda + ) 1 tingkat pendidikan petani padi sawah, akan meningkatkan pendapatan sebesar Rp. 852974.883. Koefisien regresi X3 sebesar -27355.536 menyatakan bahwa setiap penurunan (karena tanda -) 1 tingkat pengalaman berusahatani petani padi sawah, akan menurunkan pendapatan sebesar Rp. -27355.536. Untuk Koefisien regresi X4 sebesar 150956.487 menyatakan bahwa setiap penambahan (karena tanda + ) 1 orang jumlah tanggungan keluarga yang berusia produktif petani padi sawah, akan meningkatkan pendapatan sebesar Rp.150956.487.

Data koefisien regresi X5 sebesar 25524589.636 menyatakan bahwa setiap penambahan (karena tanda +) 1 hektar luas lahan garapan petani padi sawah, akan meningkatkan pendapatan sebesar Rp. 25524589.636. Adapun koefisien regresi X6 sebesar 514627.937 menyatakan bahwa setiap penambahan (karena tanda +) 1 status sosial yang berhubungan dengan usahatani padi sawah, akan meningkatkan pendapatan sebesar Rp. 514627.937. Pengaruh identitas petani terhadap pendapatan usahatani padi sawah di Kelurahan Ngkaringkaring Kecamatan Bungi Kota Baubau dapat di jelaskan sebagai berikut:

Analisa Pengaruh Umur (X1) Petani Responden Terhadap Pendapatan (Y) Usahatani Padi Sawah di Kelurahan Ngkaringkaring Kecamatan Bungi Kota Baubau. Hasil analisa regresi linear berganda digunakan untuk mengetahui pengaruh umur petani responden terhadap pendapatan usahatani padi sawah dapat melalui uji $t$ atau nilai Sig. (signifikance) seperti terdapat pada Tabel 13. yaitu menunjukkan nilai:

Sig. $=0,640$ atau probabilitas lebih besar dari 0,05.

Hasil ini menunjukkan bahwa faktor umur petani tidak memberikan pengaruh terhadap pendapatan pada usahatani padi sawah. Berdasarkan hasil penelitian, walaupun diperoleh umur petani responden sebagian besar dalam kelompok umur yang produktif yaitu 34 orang dari 42 petani responden atau $80,95 \%$, akan tetapi dari hasil analisis menunjukkan bahwa pengaruh umur terhadap pendapatan pada usahatani padi sawah adalah tidak berpengaruh. Dengan demikian bahwa baik petani yang berumur produktif maupun yang kurang produktif mempunyai motivasi yang sama untuk meningkatkan pendapatannya pada usahatani yang dikelolanya. Jadi setiap petani memiliki motivasi dalam meningkatkan pendapatannya, dan umur seseorang bukan menjadi patokan, tetapi bagaimana petani tersebut mengelolah factor-faktor produksi yang ada semaksimal mungkin untuk meningkatkan penerimaannya dari usahatani yang digeluti.

Analisa Pengaruh Pendidikan (X2) Petani Responden Terhadap Pendapatan (Y) Usahatani Padi Sawah di Kelurahan Ngkaringkaring Kecamatan Bungi Kota Baubau

Hasil analisa regresi linear berganda, untuk mengetahui pengaruh tingkat pendidikan petani responden terhadap pendapatan usahatani padi sawah diperoleh nilai Sig. (signifikance) seperti terdapat pada Tabel 13. yaitu menunjukkan nilai:

Sig. $=0,000$ atau probabilitas berada jauh di bawah 0,05.

Hasil ini menunjukkan bahwa faktor tingkat pendidikan petani memberikan pengaruh terhadap pendapatan pada usahatani padi sawah (berpengaruh). Hal ini menunjukkan bahwa tingkat pendidikan dapat mempengaruhi pola pikir petani. Petani yang berpendidikan lebih tinggi cenderung bersifat dinamis dan lebih tanggap terhadap informasi teknologi maupun 
inovasi-inovasi baru, serta selalu berupaya untuk menyelesaikan setiap permasalahan yang ditemui dalam mengelola kegiatan usahataninya misalnya adanya serangan hama dan penyakit tanaman, maka biasanya petani yang memiliki tingkat pendidikan yang lebih tinggi akan lebih agresif dalam mencari solusi terbaik agar permasalah tersebut dapat segera teratasi, sehingga akan berdampak positif pada peningkatan pendapatan yang berasal dari usahatani padi sawah yang dikelolanya.

Analisa Pengaruh Pengalaman Berusahatani (X3) Petani Responden Terhadap Pendapatan (Y) Usahatani Padi Sawah di Kelurahan Ngkaringkaring Kecamatan Bungi Kota Baubau

Hasil analisa regresi linear berganda, untuk mengetahui pengaruh pengalaman berusahatani petani responden terhadap pendapatan usahatani padi sawah diperoleh nilai Sig. (signifikance) seperti terdapat pada Tabel 13. yaitu menunjukkan nilai:

Sig. = 0,666 atau probabilitas lebih besar dari 0,05.

Hasil ini menunjukkan bahwa faktor pengalaman berusahatani petani tidak memberikan pengaruh terhadap pendapatan pada usahatani padi sawah. walaupun jumlah seluruh responden yang dikategorikan berpengalaman adalah 38 orang dari 42 orang petani responden atau $90,48 \%$.

Dari kenyataan tersebut dapat dikatakan bahwa baik petani yang berpengalaman maupun yang cukup berpengalaman dalam berusahatani mempunyai motivasi dan peluang yang sama dalam upaya meningkatkan pendapatan usahataninya, karena dari sebaran data yang ada rupanya setiap petani telah memiliki pengalaman walaupun pengalaman minimal adalah 6 tahun, namun hal ini telah memberikan gambaran tentang bagaimana bercocok tanam yang baik, sehingga dapat meningkatkan pendapatannya. Disamping itu kerjasama antara petani yang tergabung dalam kelompok tani tentunya akan mempengaruhi pengalaman petani itu sendiri.

Analisa Pengaruh Jumlah Tanggungan Keluarga (X4) Petani Responden Terhadap Pendapatan (Y) Usahatani Padi Sawah di Kelurahan Ngkaringkaring Kecamatan Bungi Kota Baubau

Hasil analisa regresi linear berganda, untuk mengetahui pengaruh jumlah tanggungan keluarga petani responden terhadap pendapatan usahatani padi sawah diperoleh nilai Sig. (signifikance) seperti terdapat pada Tabel 13. yaitu menunjukkan nilai:

Sig. $=0,574$ atau probabilitas lebih besar dari 0,05 .

Hasil ini menunjukkan bahwa faktor jumlah tanggungan keluarga petani tidak memberikan pengaruh terhadap pendapatan pada usahatani padi sawah. Berdasarkan hasil tersebut, tinggi atau rendahnya produktivitas tidak dipengaruhi oleh jumlah tanggungan keluarga, karena jumlah tanggungan keluarga yang ada tidak bekerja secara optimal dalam membantu petani responden pada saat melakukan kegiatan usahataninya, apalagi rata-rata petani baik dalam mengolah usaha taninya, menanam, menyiangi sampai memanen semuanya diongkoskan atau menyewa tenaga kerja di luar keluarga.

Analisa Pengaruh Luas Lahan Garapan (X5) Petani Responden Terhadap Pendapatan (Y) Usahatani Padi Sawah di Kelurahan Ngkaringkaring Kecamatan Bungi Kota Baubau 
Hasil analisa regresi linear berganda, untuk mengetahui pengaruh luas lahan garapan petani responden terhadap pendapatan usahatani padi sawah diperoleh nilai Sig. (signifikance) seperti terdapat pada Tabel 13. yaitu menunjukkan nilai:

Sig. $=0,000$ atau probabilitas berada jauh di bawah 0,05 .

Hasil ini menunjukkan bahwa faktor luas lahan garapan petani memberikan pengaruh terhadap pendapatan pada usahatani padi sawah (berpengaruh). Hal ini menunjukkan bahwa semakin besar luas lahan garapan yang dimiliki dan di kelola oleh petani responden, maka semakin tinggi pula pendapatan yang dihasilkan pada usahatani padi sawah tersebut, sebab luas lahan garapan akan menentukan intensitas kegiatan usahataninya karena jumlah produksi yang dihasilkan oleh petani tergantung dari luas lahan yang dikelola oleh petani. Jadi lahan merupakan salah satu faktor produksi untuk memberikan hasil dalam wujud pendapatan. Apalagi pengelolaannya telah dilakukan secara profesional, maka tidak ada masalah terhadap luas lahan yang dimiliki oleh petani, karena hal ini akan mempengaruhi petani tersebut dalam mengambil sebuah keputusan. Biasanya jika luas lahan petani kecil, maka kadangkala pengelolaannya dilakukan sendiri tanpa menggunakan tenaga kerja dari luar.

Analisa Pengaruh Status Sosial (X6) Petani Responden Terhadap Pendapatan (Y) Usahatani Padi Sawah di Kelurahan Ngkaringkaring Kecamatan Bungi Kota Baubau

Hasil analisa regresi linear berganda, untuk mengetahui pengaruh status sosial petani responden terhadap pendapatan usahatani padi sawah diperoleh nilai Sig. (signifikance) seperti terdapat pada Tabel 13. yaitu menunjukkan nilai:

Sig. $=0,648$ atau probabilitas lebih besar dari 0,05 .

Hasil ini menunjukkan bahwa faktor status sosial petani tidak memberikan pengaruh terhadap pendapatan pada usahatani padi sawah. Hal ini menunjukkan bahwa baik status sosial seseorang petani tinggi, maupun rendah sama-sama memiliki motivasi untuk meningkatkan pendapatannya yang berasal dari usahatani padi sawah guna memenuhi kebutuhan petani itu sendiri dan keluarganya.

\section{KESIMPULAN DAN SARAN}

Kesimpulan

Berdasarkan hasil analisis dan pembahasan, maka dapat dikemukakan beberapa kesimpulan sebagai berikut:

1. Tingkat Pendidikan dan luas lahan garapan dan memberikan pengaruh terhadap pendapatan pada usahatani padi sawah dengan nilai probabilitas masing-masing 0,000 dimana berada jauh di bawah 0,05 , berarti $\mathrm{H} 0$ ditolak dan $\mathrm{H} 2$ dan $\mathrm{H} 5$ diterima.

2. Umur, pengalaman berusahatani, jumlah tanggungan keluarga dan status sosial tidak memberikan pengaruh terhadap pendapatan pada usahatani padi sawah, karena masing-masing memiliki nilai probabilitas yaitu 0,640, 0,666, 0,574 dan 0.648 lebih besar dari 0,05 berarti $\mathrm{H} 0$ diterima dan $\mathrm{H} 1, \mathrm{H} 3, \mathrm{H} 4$ dan $\mathrm{H} 6$ ditolak. 
3. Identitas petani responden (umur, tingkat pendidikan, pengalaman berusahatani, jumlah tanggungan keluarga, luas lahan garapan serta status sosial) secara bersamasama memberikan konstribusi pengaruh terhadap pendapatan pada usahatani padi sawah sebesar $96,4 \%$ dan selebihnya yaitu 3,6\% dipengaruhi oleh faktor-faktor lain.

\section{Saran-saran}

Berdasarkan kesimpulan di atas, dapat dikemukakan beberapa saran sebagai berikut:

Diharapkan para petani padi sawah di Kelurahan Ngkaringkaring Kecamatan Bungi Kota Baubau dapat mengikuti penyuluhan yang dilaksanakan secara berkala oleh PPL mengenai teknologi sapta usahatani padi sawah, sebagai upaya dalam meningkatkan kemampuan dalam hal pengetahuan, keterampilan dan sikap yang dimiliki sehingga dapat menyelesaikan berbagai masalah yang dihadapi dalam kegiatan usahataninya dan pada akhirnya produktivitas dan pendapatan usahataninya dapat meningkat.

Bagi petugas PPL setempat, kiranya perlu untuk meningkatkan lagi kegiatan penyuluhan pertanian, terutama dalam memberikan informasi tentang perkembangan teknologi sapta usahatani padi sawah yang sesuai dengan anjuran yang telah ditetapkan dan pelaksanaannya disesuaikan dengan kondisi petani setempat agar petani dapat lebih efektif dalam mengelola usahataninya.

Bagi Dinas Pertanian dan Kehutanan Kota Baubau, agar menumbuhkembangkan kelompok tani yang sudah ada dimasyarakat seperti yang terdapat di Kelurahan Ngkaringkaring dengan Seke Subaknya dan selanjutnya melalui kegiatan penyuluhan pertanian, diarahkan menuju bentuk kelompoktani yang semakin terikat oleh kepentingan dan tujuan bersama dalam meningkatkan produksi, produktivitas dan pendapatan petani itu sendiri.

\section{DAFTAR PUSTAKA}

Heizer, J. dan Render, B. 2008. Operations Management. Ninth Edition. New Jersey: Pearson Education, Inc.

Lincolin A. 2008. Ekonomi Manajerial (Ekonomi Mikro Terapan untuk Manajemen Bisnis), Edisi ke-4, BPFE, Yogyakarta.

Marwadi A. 2010. Produksi Padi di Sulawesi Tenggara Tahun 2010. Kendari Pos, hal 3.

Soehardjo \& Dahlan P. 1984. Sendi-Sendi Pokok Ilmu Usahatani. UNHAS, Ujung Pandang. Soekartawi, 2006. Analisis Usahatani. Universitas Indonesia. Jakarta.

Suharsimi A. 2012. Prosedur Penelitian Suatu Pendekatan Praktek. PT. Rineka Cipta, Jakarta. 
Suyatna, I Gde. 1982. Ciri-ciri Kedinamisan Kelompok Sosial Tradisional di Bali dan Peranannya dalam Pembanguna, Tesis, Fakutas pasca Sarjana Institut Pertanian Bogor, Bogor.

Tjahjono, Heru K. 2009. Metode Penelitian Bisnis. Visi Solusi Madani, Yogyakarta.

Veithzal Rivai \& Deddy Mulyadi. 2010. Kepemimpinan dan Prilaku Organisasi. Edisi Ketiga, Rajawali Pers, Jakarta.

Widiarta, I.N. 2010. Laporan Tahunan 2009 Penelitian Padi dan Palawija. Pusat Penelitian dan Pengembangan Tanaman Pangan Badan Penelitian dan Pengembangan Pertanian.

Yosefina Marice Falloa, dkk. 2018. Faktor-Faktor yang Mempengaruhi Produksi Padi Sawah di Kecamatan Biboki Moenleu Kabupaten Timor Tengah Utara Provinsi Nusa Tenggara Timur. Agrimor 3 (4) 64-66 Jurnal Agribisnis Lahan Kering - 2018 International Standard of Serial Number 2502-1710 